\title{
A tanulmányi fegyelem a felsőoktatásban az ötvenes évek elején*
}

\author{
Polyák Petra \\ PTE Egyetemi Levéltár
}

\begin{abstract}
A Rákosi-korszak felsőoktatásában a tanulmányi hanyagság (az órai hiányzás, késés vagy bukás stb.), de a tanulmányok engedély nélküli abbahagyása is fegyelmi vétséggé vált, mely elvi szinten a tanulás munkaként való azonosításából, praktikusan a felsőoktatás szakember-utánpótlásban betöltött funkciójából következett. A szocialista tanulásszervezés a fegyelmet a diploma megszerzésének legfontosabb alapfeltételévé emelte, s a hallgatóknak a felsőoktatás ötvenes évek eleji múködési mechanizmusaival szoros összefüggésben álló tanulmányi nehézségeit is pusztán fegyelemlazulásként értelmezte.
\end{abstract}

Kulcsszavak: fegyelem, fegyelmezés, Rákosi-korszak, felsőoktatás

Ha egy hallgató nem jár be órára, nem tanul, vagy megbukik egy vizsgán, oklevele megszerzését kockáztatja, azaz magatartásának alapvetóen tanulmányi kihatása van. Az ötvenes évek elején azonban mindezek fegyelmi következményekkel is járhattak, a hallgatót akár ki is zárhatták a felsőoktatási intézményből.

Az, hogy a tanulmányi hanyagság a Rákosi-korszakban fegyelmi vétséggé vált, a felsőoktatásnak a kommunista párt totális politikai, gazdasági és társadalomalakító programjában betöltött, a korábbiakhoz képest eltérő funkciójából fakadt. Egyfelől a szovjet oktatási modellekhez igazodni kívánó pártállami oktatásirányítás a felsőoktatás egyik legfőbb feladatát abban látta, hogy biztosítsa az ötéves terv végrehajtásához szükséges mennyiségú új szakember kiképzését (Szita, 1951. 390-392. o.; Timár, 1989. 41-63. o.; Lukács, 1991. 60-62. o.). ${ }^{1}$ Másfelől a felsőoktatás ötvenes évek eleji tömegesítése szorosan összekapcsolódott a társadalmi egyenlőtlenségek csökkentésének programjával. A korabeli kultúrpolitikai megnyilatkozásokból elmaradhatatlan jelszó, ti. a „volt uralkodó osztályok múveltségi monopóliumának megtörése” azonban a felsőoktatáshoz való hozzáférés lehetőségeinek bővítésén túl - önlegitimációs megfontolásokból - a politikailag megbízhatatlannak tartott „régi értelmiség” leváltását és

*Az Emberi Erőforrások Minisztériuma ÚNKP-18-3. kódszámú Új Nemzeti Kiválóság Programjának támogatásával készült.

${ }^{1}$ A szovjet felsőoktatási modell két világháború közötti sajátosságaira és múködési mechanizmusaira lásd: Konecny, 1999; Connelly, 2000. 24-30. 
egy rendszerhú „,új értelmiségi” réteg kinevelését is célozta. Ennek érdekében az oktatásirányítás változatos módokon segítette elő az „osztályhelyzetükből” fakadóan természetes támogatóinak tekintett „munkás- és parasztszármazású" tanulók továbbtanulását, s e kedvezményezett csoport tagjai iskolaéveik alatt is sokrétú tanulmányi, anyagi és egyéb támogatásban részesültek. Mindeközben diszkriminatív eszközökkel igyekeztek távol tartani a felsőoktatási intézményektől az „osztályidegen származású" fiatalokat, azaz - meglehetősen önkényesen értelmezett fogalmi kategóriák szerint - a „kizsákmányolók”, , ,tôkések”, "kulákok” gyermekeit (Fitzpatrick, 1993/2000. 20., 28. o.; Sáska, 2006; Takács, 2008. 31-41. o.; Nagy, 2015; Polyák, 2016. 24-36. o.). A szocializmust építő „új értelmiség” képzőhelyei azonban nemcsak a szakmai felkészítés, hanem az indoktrináció színterei is voltak: az ideológiai szempontokat is közvetítő tananyag, a kötelező marxizmusoktatás és a felsőoktatás mindennapjait - az üzemekéhez hasonlóan - elborító propaganda mind-mind az új társadalmi-politikai intézmény- és értékrendszert fenntartó generáció kiformálását célozta. E célkitûzések megvalósítását szolgálta a gyakorlatban a felsőfokú képzés volumenének és a tervgazdasági igényeknek az összehangolása, a felsőoktatási intézmények napi múködésébe is beavatkozó centralizált-bürokratikus állami irányítás és az egyetemi autonómia felszámolása, az oktatás-nevelés kérdéseit közvetlenül befolyásolni igyekvő egyetemi-főiskolai pártszervezetek létrehozása, valamint az oktatói kar politikai szempontú szelektálása és kontrollja (Ladányi, 1999. 78-87. o.; Garai, 2015; Garai, 2016; Németh és Biró, 2016. 43-50., 53-55. o.; az ELTE példáján: Borsodi, 2003. 314-346. o.; a szovjet felsőoktatási modellhez igazodó keletnémet, cseh és lengyel felsőoktatás példáján: Connelly, 2000).

A tervgazdaság szakemberigényének kielégítésére, valamint a hallgatóság társadalmi-politikai összetételének átalakítására vonatkozó pártintenciók azonban nem merültek ki a puszta iránymutatásban. Az ötéves terv munkaerőigényéből levezetett felsőoktatási tervek pontosan előírták, hogy adott tanévben hány „munkás- és paraszt-” vagy „értelmiségi származású” elsőéves hallgatót kell felvenni, de azt is, hogy hány diplomást kell kibocsátani. A tervszámokat a felsőoktatásba bevonhatók merítési bázisával és a képzési kapacitások bővítésének anyagi és személyi korlátaival összevető oktatásirányítás számára kezdettől nyilvánvaló volt, hogy a nagyravágyó tervek teljesítése csak akkor lehetséges, ha a felvett hallgatókat szinte hiánytalanul eljuttatják a diplomáig, azaz minimálisra csökkentik a lemorzsolódást. Az ötvenes évek elején e fogalom alatt azonban nemcsak azt értették, hogy egy hallgató a végzettség megszerzése nélkül hagyja ott a felsőoktatási intézményt, hanem - a rövidtávú tervek teljesítésének sürgető kényszere miatt - azt is, ha az oklevelét nem az előírt idő alatt szerzi meg. ${ }^{2}$ A pártállami oktatásirányítás abból indult ki, hogy az, hogy egy hallgató biztosan és időben megszerezze oklevelét, csak és kizárólag oly módon érhetô el, ha a

\footnotetext{
${ }^{2}$ MNL OL XIX-I-1-r. A Vallás- és Közoktatásügyi Minisztérium Kollégiumának (a továbbiakban: VKM KOLL) 1950. január 24-i ülése.
} 
tanulási folyamatot a lehető legaprólékosabban szabályozzák. E szabályrendszer betartását jelölte a tanulmányi fegyelem.

A szocialista értelemben vett fegyelem azt a magatartást fejezte ki, hogy a társadalom tagjai betartják azokat a törvényeket, jogszabályokat és erkölcsi követelményeket, melyek kijelölik a társadalmi munkamegosztásban elfoglalt helyüket (Borbély és Durkó, 1957. 54-62. o.). Az ötvenes évek Magyarországán a társadalom múködését előíró szabályrendszer alapja a szocializmus (illetve távlatilag a kommunizmus) felépítésének imperatívusza volt, melynek megvalósulását a marxista-leninista ideológia szerint az biztosította, ha az - össztársadalmi érdek megnyilvánulásaként deklarált - törvényeket és normákat mindenki betartja. Az eszmerendszer végső célja a követelmények interiorizációja, tehát az öntudatos és önként vállalt fegyelem kialakítása volt, ezért elemi szerepet tulajdonított a viselkedés „helyes irányban” történő befolyásolásának, azaz a nevelésnek (Makarenko, 1949a, 1949b; Borbély és Durkó, 1957. 62-69. o.; Ágoston, 1962. 158-193. o.). Ugyanakkor a meggyőzésen túl a kényszerítő jellegú eszközöket is elengedhetetlennek tartotta a közös célokat veszélyeztető renitensek megfegyelmezésére. Mivel a pártállam ideológiai érvrendszere a jogi-erkölcsi előírások megsértését nem pusztán a politikai hatalom birtokosainak aktuális céljaival való szembeszegülésként, hanem az össztársadalmi célkitûzések akadályozásaként is értelmezte, a rendbontókkal szemben alkalmazott fegyelmi intézkedések elvi célja az volt, hogy a fegyelmezetlen kisebbséget alárendelje a „többségi akaratnak”, s végső soron - vagyis ha a nevelés különféle módszerei és eszközei kudarcot vallottak - biztosítsa a társadalom zavartalan fejlődését (Weltner, 1950. 64-67. o.; Csatár, 1951. 698. o.; Borbély és Durkó, 1957. 63. o.).

Jelen tanulmányban e szocialista értelemben vett fegyelemnek a felsőfokú tanulmányok folytatásában játszott szerepével foglalkozom 1948 és 1953 között. Az elemzés a felsőoktatás szovjetizálását megindító, 1948. évi, ún. egyetemi reformtól az új szakasz hangsúlyváltásait követő korrekciókig terjedő időszakot fogja át, tehát a Rákosi-korszak azon a periódusát, amelyben a tanulmányi fegyelem megsértése akár kizárással fenyegető vétségnek minősült. A kérdéskört először - a korabeli politikai és propagandamegnyilvánulások alapján - a tanulásra vonatkozó, hivatalos diskurzus változásán keresztül közelítem meg, ezt követően pedig azt vizsgálom, hogy mindez milyen közvetlen következményekkel járt a felsőfokú tanulmányok folytatásának mindennapjaiban. Végül pedig több mint négyszáz, tanulmányi vétség miatt indított (s többségében kizárással végződő) eljárás dokumentációja alapján a szankcionálás konkrét intézményi gyakorlatát mutatom be.

Az elemzés forrásanyagát a mindenkori oktatási minisztériumok, ${ }^{3}$ illetve fel-

\footnotetext{
${ }^{3}$ A felsőoktatás állami irányítása 1951-ig a Vallás- és Közoktatásügyi Minisztériumhoz, 1951 és 1952 között a Közoktatásügyi Minisztériumhoz tartozott. Az 1952 végén létrehozott Felsőoktatási Minisztérium csak néhány hónapig múködött, ezt követően, 1953 nyarán a Felsőoktatási és a Közoktatásügyi Minisztérium összeolvasztásával az oktatás az Oktatásügyi Minisztérium (OM) irányítása alá került.
} 
sőoktatási kérdésekben illetékes központi pártszervek ${ }^{4}$ Magyar Nemzeti Levéltár Országos Levéltárában őrzött iratanyaga jelenti. A vizsgált időszakban a mindenkori (felső)oktatási minisztérium felelt azért, hogy valamennyi egyetem és főiskola oktató- és nevelőmunkájában egységes elvi, pedagógiai és módszertani szempontok érvényesüljenek, ám az egyes felsőoktatási intézmények a profiljuknak megfelelő szakminisztérium irányítása alatt álltak (Ladányi, 1986. 36-38. o.). Jelen kutatás során a forrásfeltárás a mindenkori (felső)oktatási minisztériumok irataiban található fegyelmi dokumentációra terjedt ki, mely legrészletesebben az e minisztériumok által felügyelt felsőoktatási intézmények - ti. a tudományegyetemek bölcsész-, természettudományi és jogi karai, egyes múszaki felsőoktatási intézmények, pedagógiai főiskolák, Idegen Nyelvek Főiskolája ügyeit tartalmazza. Ám abból fakadóan, hogy az ország összes egyeteméről és főiskolájáról való kizárást a mindenkori (felső)oktatási miniszterrel is egyeztetni kellett, s a minisztérium a hivatalos ügyrenden túl gyakran kért jelentéseket a felügyelete alá nem tartozó intézmények fegyelmi ügyeiről is, az iratanyagban szinte valamennyi intézményből találhatunk eseteket. Az iratmegmaradás esetlegessége miatt azonban a megőrződött dokumentáció egyik intézmény esetében sem teljes. A jelen dolgozat alapját képező, valamivel több mint négyszáz fegyelmi eset megközelítőleg felét tudományegyetemi karokon, negyedét múszaki egyetemeken bonyolították le, ezen túl főként pedagógiai főiskolák, valamint a közgazdasági, illetve agrártudományi felsőoktatási intézmények fegyelmi eseteinek vizsgálatára nyílt mód. A feldolgozott esetek nagyjából fele fővárosi, fele vidéki felsőoktatási intézményekhez köthető.

\section{A TANULÁS MINT MUNKA}

A felsőoktatás szovjet típusú átszervezése közepette jelentősen átalakult a felsőfokú tanulmányok folytatásának, s általában a tanulásnak a diszkurzív környezete. ${ }^{5}$ A tanulás kommunista értelmezése ugyanis elvetette, hogy a diploma megszerzése kizárólag egyéni érdekeket szolgálna, ezzel szemben úgy tekintette, hogy a hallgató azért tanul, hogy elsajátított ismereteit minél előbb a társadalom rendelkezésére bocsáthassa. ${ }^{6}$ A propagandamegnyilvánulásokban a tanulás

\footnotetext{
A minisztériumok szervezetéről, irányításáról bővebben lásd Ladányi, 1986. 228-229. o.; T. Kiss, 1993. 90-120. o.

${ }^{4}$ A felsőoktatás kérdéseivel 1949 nyarától a Magyar Dolgozók Pártja (MDP) Központi Vezetőségének Oktatási Osztálya, 1950 tavaszától pedig az Agitációs és Propaganda Osztály foglalkozott, melynek irányító szerve az Agitációs és Propaganda Pártkollégium (utóbb Bizottság) volt.

A feladatkör 1954 júliusában az oktatási és kulturális propaganda területétől leválasztva a Tudományos és Kulturális Osztályhoz került. A felsőoktatás pártirányításáról bővebben lásd Ladányi, 1986. 227-228. o.

${ }^{5}$ Bár e kérdéskörrel nem foglalkozom, szükséges megemlíteni, hogy a tanulás kommunista értelmezése és az ebből fakadó konzekvenciák - persze eltérő hangsúlyokkal, de - az alap- és középfokú oktatási intézmények diákjaira is érvényesek voltak.

${ }^{6}$ Lásd például: Lukács György: Az új egyetem munkaerkölcséről. (1948.10.20.) Fiatal Magyarország, 5 .
} 
hazafias kötelességként jelent meg, ám a szocialista hazafiság értelmében, mely a haza szeretete alatt (többek között) a „,szocializmust építő haza jelenének és kommunista jövőjének" szeretetét értette (Sarija, 1951. 124-127. o.; Darvas, 1952. 552. o.; Siskin, 1955. 212-234. o.), az 1948 elején felbukkanó, "Tanulj többet, hazádat építed!" jelmondat második felében a haza helyét fokozatosan a szocializmus vette át.

A szocializmus építésében a minél magasabb színvonalú tanulással való közremúködést azonban nem pusztán az e célokért lelkesedők belső késztetéseként értelmezték, az az1951-ben kiadott tanulmányi, fegyelmi és vizsgaszabályzat szerint nemcsak valamennyi hallgató alkotmányos joga, hanem "megtisztelo" és „becsületbeli" kötelessége is volt. ${ }^{7}$ Ennek teljesítését a pártpropaganda rendszeresen párhuzamba állította a munkával, mondván: a tanulás „olyan kötelessége minden egyetemistának, mint a munkásnak a norma teljesitése, vagy a dolgozó parasztnak az időbeni szántás, vagy vetés", 8 mivel a "szocializmus eredményes építéséhez ugyanúgy hozzátartozik az önfeláldozó tanulás, mint az önfeláldozó munka". 9 A tanulás munkaként való azonosításából fakadóan a szocialista munkaerkölcs kritériumai a tanulmányi munkára is kiterjedtek: a tanulmányi fegyelem ily módon nem sokban különbözött az üzemi dolgozók munkafegyelmére vonatkozó előírásoktól (Krémer, 1950; Weltner, 1950; Csatár, 1951; Siskin, 1955. 189-212. o.). A munkához való viszony ideáltipikus értelmezése alapján a hallgatóknak saját „munkaterületükön” fel kellett ismerni, hogy a tanulással nemcsak saját, hanem a szocializmus mielőbbi felépítését (az uralkodó politikai diskurzus szerint: az egész társadalom érdekét) szolgálják. De azzal is tisztában kellett lenniük, hogy a tanulmányi rendszabályok a "tanulás fokozására” és az azt akadályozó körülmények kiküszöbölésére irányulnak, vagyis betartásuk saját érdekük, ezért ezeket önként (ti. kényszerítő eszközök alkalmazása nélkül is) végre kell hajtaniuk. Minthogy a munkafegyelem megszilárdítására vonatkozó pártintenciókat is szinte szó szerint alkalmazták az egyetemekre és a főiskolákra is, a tanulmányi fegyelemre nevelés idealisztikus célja az volt, hogy a hallgatók között olyan „közhangulat” alakuljon ki, amely a tanulást „becsület és dicsőség dolgának" tekinti; nem tû́ri a fegyelem lazítását, a hanyagokat, lustákat és "lógósokat" megbélyegzi, és kötelességeik teljesítésére kényszeríti őket (Ágoston, 1952a, 1952b; Borbély és Durkó, 1957. 53-93. o.; vö. Makarenko, 1949a).

A tanulás és a termelés, a felsőoktatási intézmények és az üzemek azonosítása azonban nemcsak a pártpropaganda nyelvi szintjén és erkölcsi követelmények megfogalmazásában nyilvánult meg, hanem a szovjet ideológiai-pedagógiai

\footnotetext{
${ }^{7}$ A vallás- és közoktatásügyi miniszter, a földmúvelésügyi miniszter és az egészségügyi miniszter 1400-65-11/1951. (II. 18.) V. K. M. számú rendelete az egyetemek és főiskolák általános tanulmányi, fegyelmi és vizsgaszabályzatának megállapítása tárgyában. Magyar Közlöny - Miniszteri rendeletek, 1951. 29. sz. 199-206. (A továbbiakban: TFVSZ 1951).

${ }^{8}$ Gosztonyi János: Egyetemi munkánk hibáiról. (1950.10.06.) Szabad Ifjúság, 7.

${ }^{9} \mathrm{Az}$ osztályöntudat tegye kötelességévé minden munkásfiatalnak, hogy tovább tanuljon. (1950.06.02.) Szabad Ifjúság, 5.
} 
megfontolások egyetemi-főiskolai környezetre való kiterjesztésével a gyakorlatban is. Az iskola és a munka világának szoros összekapcsolása a szovjet modellt követő oktatási rendszerek immanens része volt, mely egyfelől megmutatkozott a tervgazdaság szakemberigényének és a (szak)képzési kapacitások szoros összehangolásában, de abban is, hogy a képzési tartalmakat - az ideológiai szempontokon túl - elsősorban a „gyakorlati élet követelményei”, ti. a leendő munka elvégzéséhez szükséges (illetve elégségesnek gondolt) ismeretek szempontjából súlyozták és szelektálták. Így például az orvosképzésben a minél gyorsabban munkába állítható gyakorló orvosok kiképzése, a bölcsészkarokon a tanárképzés és az egyes iskolatípusok pedagógusigényei, a jogászképzésben a munka- és gazdaságjog oktatása, a mérnökképzésben az üzemi tervgazdálkodás kérdései kerültek előtérbe. ${ }^{10}$

Másfelől az oktatás-nevelés, valamint a termelőmunka összekapcsolása a „sokoldalúan fejlett emberek” kiképzésének marxi koncepciójából levezetett, de olykor reformpedagógiai hivatkozásokkal is megtámogatott szovjet pedagógiai nézeteknek is alapeleme volt (Golnhofer, 2004; Somogyvári, 2016). Míg a politechnikai képzés koncepciója a közoktatásban elsősorban a termelés egyes ágainak, illetve technikai alapkészségek megismertetését célozta, a szakképzésben és a felsőoktatásban az „elmélet és a gyakorlat egysége” főként a képzési területhez kötődő, üzemekben, termelőszövetkezetekben eltöltött szakmai-termelési gyakorlatok kibővítésével jutott érvényre. A termelési gyakorlatok elvben arra voltak hivatottak, hogy a hallgatók közvetlenül is megismerkedjenek az adott szakterülethez tartozó valamennyi munkafolyamattal, a fizikai és a szellemi munkát igénylő posztokon egyaránt, hogy majdan frissdiplomásként hatékonyan ültethessék át a szocialista munkaszervezésről és -módszerekről szerzett tankönyvi tudásukat a gyakorlatba (vö. Konecny, 1999. 144-145. o., 176-197. o.). A praktikus ismeretek megszerzésén túl a termelőmunka oktatási-nevelési eszközként való alkalmazása, a szellemi és fizikai munka oktatási rendszeren keresztül történő közelítése messzemenő politikai-ideológiai célokat is szolgált, tőle a fizikai munka megbecsülését, tágabb dimenzióban a „munkásosztály vezetőszerepének” elismerését remélték, s azt, hogy az „osztályhelyzetüknél” fogva megbízható(nak vélt) „munkásosztállyal” és a termelőszövetkezeti csoportok tagjaival kialakított közvetlen kapcsolat a diákok ideológiai-politikai nevelésére is pozitív hatást gyakorol (Falusné, 1955; Fukász, 1961; Fukász, 1962).

A tervgazdasági munkaszervezés mechanizmusai hangsúlyosan jelentkeztek a hallgatók (és az oktatók) teljesítményének megítélésében is. A felsőoktatási munka sikerének mércéjét ugyanis a mindennapokban nem a szocializmus jövőbeli felépülése jelentette, az intézmények „normái” az olyan megszámlálható eredmények lettek, mint a felvettek és végzettek ötéves terv alapján meghatározott létszáma és szociális megoszlása, tanulmányi átlaga. A hallgatók

\footnotetext{
${ }^{10}$ MNL OL M-KS 276-89/305. Az MDP KV APO jelentése az egyetemi reformjavaslatok elvi szempontjairól és végrehajtásának biztosításáról. Budapest, 1950. július 25.; MNL OL XIX-I-1-r. VKM KOLL 1950. október 30-i ülése.
} 
tervteljesítésben betöltött szerepét a Dolgozó Ifjúság Szövetsége (DISZ) egyik 1951-es feljegyzése ellentmondást nem túrő hangon jelölte ki: „Minden egyetemi hallgató vizsgája alkalmával a szocializmust épitö magyar haza államával szemben teljesíti kötelezettségeit, mint munkásaink a termelés fokozásával, dolgozó parasztjainak a beadás teljesítésével. A diákfiataloktól azt várja Pártunk, hogy időben és jó eredménnyel vizsgázzanak. (...) A terv - törvény - pontos végrehajtása kötelező mindenki számára. A hallgató tervszabta kötelessége a jó eredményü és időben történő vizsgázás. Aki vizsgájára hanyagul készül, vagy nem vizsgázik, népünk akaratával kerül szembe, tette törvényszegéssel egyenlo"."11

A felsőfokú tanulmányok fegyelmezett folytatása túlmutatott tehát a puszta erkölcsi kötelességeken, a hallgatók számára pedig jogi kényszerré is vált: ez képezte a társadalmi munkamegosztásban számukra kijelölt feladatot, melynek teljesítése az 1949-es alkotmány értelmében nem egyéni elhatározás függvénye volt, hanem kötelező, ugyanúgy, ahogy saját munkaterületének ellátása minden „munkaképes polgár" számára. ${ }^{12}$ E megfontolásra vezethető vissza, hogy a tanulmányok hanyag végzése fegyelmi vétséggé vált. Az ötvenes évek eleji intézményi (üzemi, felsőoktatási) fegyelmi szabályzatokban a munkavégzéssel összefüggő vétségek szankcionálását az ideológiai érvelés azzal legitimálta, hogy az elvégzendő (esetünkben: „tanulási”) munka a szocializmus felépítését szolgáló ötéves terv része, a tervgazdálkodást folytató államnak pedig törvényi kötelessége ezt a tervet „megvédeni”, s adminisztratív eszközök alkalmazásával is fellépni a „munkafegyelem frontján” jelentkező, kirívó fegyelemsértésekkel szemben (Gyekiczky, 1989. 62-63. o.).

A hallgatók tervgazdálkodásban betöltött szerepét jól mutatja, hogy a tanulmányok engedély nélküli megszakítása is fegyelmi büntetést vonhatott maga után. A tervteljesítést ugyanis nagyban veszélyeztette volna, ha valaki bármikor, önszántából abbahagyhatja tanulmányait, ezért az 1951-es tanulmányi, fegyelmi és vizsgaszabályzat szabályzat kimondta, hogy a "hallgató köteles tanévenként a beiratkozásra megállapított időben beiratkozni."13 E paragrafus nem a beiratkozás előírt időpontjainak betartatására szolgált, hanem a beiratkozás kötelezettségét rögzítette, melyet a szabályzat egy korábbi szövegváltozata a rendelkezés alapelvének tekintett: „Az egyetem a hallgatók munkahelye, az egyszer beiratkozott hallgató mindaddig tagja az egyetemnek, amíg tanulmányait sikeresen be nem vég$z i^{\prime \prime}{ }^{14}$ Az önkényes kimaradás engedély nélküli lemorzsolódásnak minősült, melyet általában kizárással büntettek. Az engedélyezett lemorzsolódás és a kizárás intézményi szempontból végső soron ugyanarra az eredményre vezetett, utóbbi azonban a hallgatóra nézve számos hátrányos következménnyel járt. A kizártak

\footnotetext{
${ }^{11}$ MNL OL M-KS 276-89/312. Javaslat a félévi vizsgákkal kapcsolatos feladatokkal [sic!]. Budapest, 1951. november 30 .

121949. évi XX. tc. 9. §1., 2.

${ }^{13}$ TFVSZ 1951. 8. § (5).

${ }^{14}$ MNL OL XIX-I-1-r. VKM KOLL 1950. november 24-i ülése. Kiemelés az eredetiben.
} 
elveszítették addigi féléveiket és tanulmányaik folytatásának lehetőségét is, ${ }^{15}$ egy 1952-es rendelet értelmében pedig ösztöndíjuk visszafizetésére kötelezhették őket. ${ }^{16}$

A propagandamegnyilvánulásokban a tanulás az ötvenes évek elejétől önmagán túlmutató jelentőségúvé vált: a hallgatók "több” és ,jobb” tanulással „harcoltak” „az emberiség boldog jövőjéért”, amely felé „a Párt vezet”, az „imperialisták" ellen, fejezték ki szeretetüket Sztálin és Rákosi Mátyás iránt, erősítették a békefrontot stb. A tanulás - ahogy a munka - politikai cselekedetté vált, amely a hallgató társadalmi-politikai berendezkedéshez fúződő viszonyát fejezte ki: „[A]hogy az üzemben döntő kérdés a termelés kérdése, ugyanígy az egyetemen a tanulást kell a legfontosabb feladatnak tekinteni. (...) [A]z egyetemeken a diákoknak a népi demokráciához való hüségét azzal lehet a legjobban lemérni, hogyan tanulnak, milyen vizsgaeredményeket érnek el."17 Minthogy az egyéni tanulmányi eredmény a szocialista építés kontextusában nyert értelmet, nemcsak egy-egy hallgató képességeiről vagy motivációiról tanúskodott, hanem a politikai hatalom birtokosainak szemében arról is, hogy mennyire igyekszik megfelelni a központi elvárásoknak (vö. Kotkin, 1995. 207. o.; Konecny, 1999. 154., 159-161. o.; Szabó, 2007. 158-164. o.).

\section{TANULÁSSZERVEZÉS A SZOVJETIZÁLT FELSŐOKTATÁSBAN}

A felsőoktatási intézmények ötvenes évek eleji erőltetett tömegesítése szükségszerú hatást gyakorolt az oktatás, képzés folyamataira. Egyfelől a nagyszámú elsőéves megjelenése átalakította az oktatás rendjét és megnövelte a kezdő évfolyamokkal való foglalkozás feladatait, másrészt annak következtében, hogy a felvételre kerülők körét elsősorban társadalompolitikai szempontok szerint alakították ki, nagy számban kerültek be olyanok a felsőoktatási intézményekbe, akiket középiskolai tanulmányi eredményük vagy a felvételi vizsgán nyújtott teljesítményük nem predesztinált volna felsőfokú tanulmányok folytatására (Sáska, 2006; Polyák, 2016; a diákok tanulmányi teljesítménye és szociális összetétele közti összefüggésekre az ötvenes évek eleji általános és középfokú oktatás vonatkozásában lásd Knausz, 1988/1998). Az oktatásirányítás a nem megfelelő előképzettséggel bekerülők tanulmányi nehézségeit, valamint azt, hogy lehetőleg mindenki az előírt idő alatt szerezze meg oklevelét, a tanítási-tanulási folyamat rendkívül aprólékos szabályozásával, széleskörú propagandával és a lemaradók szüntelen agitálásával igyekezett pótolni. A szocialista oktatásés tanulásszervezés szinte kézen fogva próbálta átvezetni - ha az agitáció in-

\footnotetext{
${ }^{15}$ TFVSZ 1951. 23. § (4).

1640/1952. (V. 11.) M. T. sz. rendelet a tanulmányaikat félbenhagyó vagy azokból fegyelmileg kizárt hallgatók ösztöndíjának visszatérítéséről [sic!]. Közoktatásügyi Közlöny, 2. 1952. 10. sz. 118-119.

${ }^{17} \mathrm{Az}$ egyetemi félévi vizsgák színvonalának emeléséről és az új tanulmányi rendtartásról tárgyalt az egyetemek vezetőinek értekezlete. (1950. 12. 06.) Szabad Nép, 5.
} 
tenzitását nézzük, azt is mondhatjuk, hogy ",áttuszkolni” - a hallgatókat az egyetemi-főiskolai éveken.

Az oktatás- és tanulásszervezés jelszavai a rendszeres/folyamatos, illetve az egyéni tanulás lettek. A folyamatos tanulás koncepciója azt célozta, hogy a hallgatók ne csak a vizsgaidőszakban ún. „kampány-” vagy „rohamtanulással”, tehát rendszertelenül és esetlegesen készüljenek fel a vizsgáikra, hanem egész évben szervezetten és folyamatosan tanuljanak. E gondolat egyik legsajátosabb propagandamegnyilvánulása a "Tanuld meg még ma, amit ma előadtak!" buzdító jelmondat volt. ${ }^{18}$ A folyamatos tanulás azonban több volt, mint módszertani ajánlás: a szabályzat a hallgatók kötelezettségeit úgy állapította meg, hogy idejük lehető legnagyobb részét lefedje kötelező vagy erősen ajánlott foglalkozásokkal. A félév közbeni vizsgákkal, tanulmányi versenyekkel pedig igyekeztek rávenni okket arra, hogy a fennmaradó időben is folyamatosan tanuljanak.

Az oktatás kötelező formái közé az előadások, szemináriumok és különféle gyakorlatok tartoztak, melyek heti óraszáma 35-40 körül mozgott. Ezeken túl kiegészítő foglalkozások (szakkörök, konzultációk, tanulókörök stb.) jelentették a tanulás szervezett alkalmait, melyek a kötelező órákkal együtt ideális esetben heti kb. 70 órát töltöttek ki. ${ }^{19}$ Mivel az oktatásirányítás szerint az ismeretek elsajátításának legfőbb előfeltétele az oktatás e szervezett formáiban való részvétel volt, a tanulmányi fegyelem egyik legfontosabb fokmérőjévé a fizikai jelenlét vált, az igazolatlan hiányzást pedig - mértékétől függően - a legenyhébb fegyelmi büntetéstől, a figyelmeztetéstől kezdve akár kizárással is sújthatták.

A vizsgarendszer átalakításával ekkortól valamennyi kötelező tárgy hallgatását vizsga (kollokvium) követte. A beszámoltatás különféle formái a félévi vizsgáktól kezdve az évközi kisvizsgákon, villámzárthelyiken, beadandókon keresztül a feleltetésig bontották egyre kisebb és kisebb időegységekre a tanévet, egészen a tanórák szintjéig: az ezeken való "tényleges szellemi részvételt" 20 az órai jegyzetekkel kellett bizonyítani. A képzés belátható részegységekig való felbontása a foucault-i fegyelmező idő funkcióit töltötte be: egyrészt a rendelkezésre álló időkeret lehető leghatékonyabb - korabeli megfogalmazásban: „tervszerü" - kihasználását szolgálta, de azt is, hogy a hallgatók teljesítményéért felelős szervek - a tanszékek, a tanulmányi osztály vagy a pártszervezet - még a félév/tanév befejezése előtt információt szerezzenek a hallgatók előrehaladásáról, főként a beavatkozást igénylő lemaradásokról (Foucault, 1990. 203-219. o.; vö. Németh, 2014. 48-53. o.).

Mivel a kötött tantervek kizárták a fakultativitást, a rendszeres ellenőrzése-

\footnotetext{
${ }^{18}$ Tátrai Béla: „Tanuld meg még ma, amit ma előadtak”. (1952. 02. 14.) Szabad Nép, 4.

${ }^{19}$ MNL OL M-KS 276-89/312. A Budapesti Múszaki Egyetemen f. évi október 24-én a folyamatos tanulás biztosítása tárgyában tartandó ankét bevezető előadásának vázlata. Budapest, 1951. október 17.

${ }^{20}$ MNL OL M-KS 276-89/312. A Budapesti Múszaki Egyetemen f. évi október 24-én a folyamatos tanulás biztosítása tárgyában tartandó ankét bevezető előadásának vázlata. Budapest, 1951. október 17.
} 
ken keresztül minden hallgató tanulmányi teljesítménye azonos kritériumok szerint vált mérhetővé és összehasonlíthatóvá, az előrehaladás (a következő tanévre való beiratkozás) pedig csak ezeken az egymásra épülő, hierarchizált fázisokon keresztül vált lehetségessé (vö. Foucault, 1990. 214-215. o.). Ebbe az időkeretbe a tanulmányaikat még a Horthy-korszak képzési rendje szerint megkezdőket is belekényszerítették: a VKM 1950 júliusában rendelte el, hogy az 1950/51. tanévre csak az iratkozhat be, akinek semmilyen vizsgaelmaradása nincs. Azok a hallgatók, akiknek elmaradt vizsgájuk volt, szeptember végéig kaptak lehetőséget, hogy letegyék azokat, ellenkező esetben csak az utolsó, minden vizsgát tekintve sikeresen befejezett évet követő évfolyamra iratkozhattak be. $^{21}$

A képzés egymásra épülő fokozatokra való bontása nem csak azt jelentette, hogy a hallgató továbbhaladása az e fokozatokhoz kapcsolt vizsgák teljesítésétől függött. Mivel - ahogy a szabályzat egyik korai szövegváltozata fogalmazott - „a dolgozó nép fiaiból és leányaiból az előírt ido” alatt, évveszteség nélkül"22 kellett kiképezni a szocializmus jövendő építőit, a bukás is a tanulmányi rend megsértésének minősültt. ${ }^{23}$ A bukottak fegyelmi büntetésének mértéke az elbukott vizsgák számától, illetve a nem teljesített tárgytól függött. Előbbi tulajdonképpen azt jelentette, hogy a tanulmányi elégtelenség fegyelmi vétséggé vált, utóbbi pedig azt, hogy a marxizmus-leninizmusból a pótvizsgákon is elbukó hallgatókat gyakran automatikusan kizárták.

E szigorúan szabályozott időterv az oktatókat ugyanúgy kötötte, mint a hallgatókat. A tanulás ritmusát a központilag előírt vizsgaidőpontok jelölték ki, a tantervek és óratervek központi jóváhagyása viszont - a tananyag megfelelő ideológiai alátámasztásának ellenőrzése mellett - azt is követhetővé tette, vajon ezek közlése óráról órára megfelelő ütemben zajlik-e. Így egy oktatót azért is elmarasztalhattak, ha meghosszabbította egy dolgozat leadási határidejét. ${ }^{24}$

A tanszékek korábban nem tapasztalt mértékú felelősséget viseltek hallgatóik előmeneteléért: folyamatosan követniük kellett előrehaladásukat, felderíteni problémáikat, de segítséget is biztosítaniuk kellett - szakmai problémák esetén konzultációkkal, egyéb esetben a tanulmányi osztály értesítésével, s eközben mindvégig kiemelt figyelemmel kellett kísérniük a szakérettségisek és általában a „munkás- és parasztszármazású" hallgatók előmenetelét. ${ }^{25}$

A ,tervszerú tanulmányi munka" ellenőrzését biztosította a tanulmányi csoportok kialakítása is. E csoportok egy szak azonos évfolyamán tanuló, 15-30

\footnotetext{
${ }^{21}$ MNL OL XIX-I-1-h. 250. doboz, 1400-65-81/1950. Utóvizsgák (pótvizsgák) határidejének megállapítása és elmaradt vizsgák (kollokvium, szigorlatok) felszámolása. Budapest, 1950. július 24.

${ }^{22}$ MNL OL XIX-I-1-r. VKM KOLL 1950. november 24-i ülése.

${ }^{23}$ TFVSZ 1951. 17. § (5).

${ }^{24}$ MNL OL M-KS 276-89/328. Az 1951/52-es tanév tanulmányi és politikai munkájának értékelése az egyetemi és főiskolai pártszervezetek jelentései alapján. Budapest, d. n.

${ }^{25}$ MNL OL XIX-I-1-h. 250. doboz, 1400-57-27/1950. A tanszékek munkájának megszervezése. Budapest, 1950. szeptember 5.; MNL OL XIX-I-1-h. 249. doboz, 1400-52-22/1950. A rendszeres tanulás biztosítása. Budapest, 1950. november 9 .
} 
hallgatóból kialakított „brigádok” voltak, melyek létrehozása a makarenkói pedagógia, valamint a munkahelyi kollektívák munkafegyelmére vonatkozó pártiniciatívák egyetemi-főiskolai környezetre való adaptálását jelentette. A tanulmányi csoportoknak olyan kommunista értelemben vett közösségekként kellett funkcionálniuk, melyek tagjai egy közös cél elérése - perspektivikus értelemben a szocializmus új értelmiségévé válás, konkrétabban például a félévi vizsgák eredményes letétele - érdekében munkálkodnak.

A feladatok végrehajtása során a csoport tagjai nemcsak saját munkájukért voltak felelősek, hanem a közösség teljesítményéért is, s fordítva: a közösségnek is felelősséget kellett vállalnia tagjai munkájáért, vagyis szükség esetén megfelelő eszközökkel - rábeszéléssel, bírálattal, tanulmányi segítséggel stb. - kellett elérnie, hogy a lemaradó ne akadályozza a közösség céljainak elérését (Makarenko, 1949c. 116-117., 125-126. o.; Ágoston, 1952a; Siskin, 1955. 159. o.).

E makarenkói kiscsoportok létrehozásának célja az volt, hogy a hallgatóságot olyan kis létszámú közösségekre bontsa, amelyeken keresztül a tanulmányi, erkölcsi, ideológiai követelményeket minden egyes hallgatóhoz közvetlenül el lehet juttatni, valamennyiük teljesítménye láthatóvá, megfigyelhetővé válik, s az erről szerzett információk is - vonatkozzanak a tanulmányi lemaradásra vagy ellenséges beállítottságra - eljutnak a megfelelő „szervekhez”. A tanulmányi csoportok mint virtuális, fegyelmező terek a tanulmányi osztályok, a tanszékek, valamint a párt- és DISZ-szervezetek munkáját kiegészítve tagjaik ",társadalmi ellenőrzését" látták el (vö. Foucault, 1990. 193-203. o.; Konecny, 1999. 152-154. o.; Connelly, 2000. 62-63. o.).

A szocialista tanulásszervezés a szervezett foglalkozásokon is túlterjeszkedett. A hallgatók tanulmányi munkájának alapja ugyanis az egyéni tanulás volt, mely elnevezésével a saját tanulmányok iránti felelősséget volt hivatott hangsúlyozni, de elsősorban arra utalt, hogy a különféle szervezett alkalmakon túl is tanulni kell. A folyamatos tanulás kötelező és erősen ajánlott formái mögött azonban az egyéni meglehetősen háttérbe szorult, főként, mert ténylegesen is alig maradt idő a tanulmányi munka önálló megszervezésére. A saját tanulmányok iránti felelősség ugyanis nem jelentett önállóságot: az egyéni tanulásra fordított időt az oktatóknak házi feladatokkal kellett kitölteniük (vö. Németh, 2014. 128-133. o.; Connelly, 2000. 62-65. o.).

Az idő egyéni beosztását a diákszállókon a takarékossági okokból bevezetett, kötelező villanyoltás is korlátozta, de egy hallgató egyedül arról sem dönthetett, hogy mikor szeretne vizsgázni, vizsgaterve ugyanis a tanulmányi csoportnak volt, az összes tagnak egy tárgyból csak azonos időben lehetett felelnie, s elítélendő volt, ha valaki szándékosan bukott meg annak érdekében, hogy az utóvizsgán jobb jegyet szerezhessen.

A jobb jegyért vizsgázó hallgatókat gyakran minősítették karrieristának, s azzal vádolták őket, hogy vétettek a vizsgarend ellen, mivel egyéni érdekeik (például a jobb jeggyel elérhető magasabb ösztöndíj) háttérbe szorították a tanulmányi csoport érdekét, ti. hogy a félévi kimutatásokban minél kevesebb 
legyen az utóvizsgák száma. ${ }^{26}$

Az egyéni tanuláson túli időt politikai körök, DISZ-rendezvények csökkentették minimálisra, ezek szervezésének és elrendezésének célja a hallgatók idejének közösségi keretekben történő, lehetőleg maximális lefedése és kihasználása volt. A központi jelentésekben rendszeresen bírálták azokat az órarendeket, amelyekben lyukasóra is volt, mondván: a hallgatók ilyenkor csak ",csellengenek". ${ }^{27}$ De az egyéni tanulást követően fennmaradó időt sem tekintették „szabad időnek": a budapesti jogi kar DISZ-bizottsága már 1950-ben felhívta a pártközpont figyelmét, hogy az elsősök között „veszélye fenyeget a lazaságnak”, mivel nincs szombaton semmilyen elfoglaltságuk, így azt nagy részük „vikkendnek tekinti és nem használja fel a tanulás céljaira. [sic!]”28.

Ha a hallgatók szabadidejét nem is sikerült teljes mértékben kitölteni ideológiai-nevelési szempontból hasznos foglalatosságokkal, azt azonban kikötötték, hogy mit nem csinálhatnak: a nappali tagozatos hallgatók nem vállalhattak munkát. Azzal a veszéllyel, hogy a hallgatók a gyorsabb pénzhez jutás és magasabb fizetés reményében állást vállalnak, s emiatt lemorzsolódnak, kezdettől fogva számolni kellett, főként olyan képzések esetében, amelyek egyelőre felsőfokú végzettség nélkül is betölthető munkakörre képesítettek. ${ }^{29}$ Az ipar elszívó hatása a múszaki és természettudományi szakokon tanulók esetében volt különösen erős, utóbbiak számára ráadásul a pedagógusfizetésnél is jobb kilátásokkal kecsegtetett. ${ }^{30}$ 1951-ben és 1952-ben a hallgatók alkalmazásának kérdéseit minisztertanácsi rendeletek szabályozták, melyek kimondták, hogy a nyári szüneten kívül csak „különleges érdek fennforgása” esetén lehet nappali tagozatos hallgatót alkalmazni, és kizárólag a dékán (igazgató) engedélyével. ${ }^{31} \mathrm{Az}$ engedély nélküli munkavállalás azonban a tiltás ellenére is gyakori volt, amelyet az is lehetővé tett, hogy a szakképzett munkaerő hiánya miatt a munkáltatók is hajlamosak voltak eltekinteni az engedélyek beszerzésétől. ${ }^{32}$

A tanulás propagandája átszőtte a felsőfokú tanulmányok folytatásának mindennapjait, a vizsgák közeledtével pedig az agitáció rendszerint magasabb fokozatra kapcsolt, és a jó vizsgaeredmények elérését a szocializmus felépítése, a béke megvédése vagy valamely aktuális pártiniciatíva teljesítése érdekében kifejtett „harci feladatként” propagálta. Az Egri Pedagógiai Főiskola oktatói

\footnotetext{
${ }^{26}$ Lásd például: MNL OL XIX-I-2-f. 125. doboz, 847/855-V32/2/1954. V. D. jellemzése. Budapest, 1952. március 11.

${ }^{27}$ MNL OL M-KS 276-89/305. Jelentés az egyetemi reformról. H. n., d. n.

${ }^{28}$ MNL OL M-KS 276-89/305. Állam és Jogtudományi Kar DISZ Bizottságának jelentése. H. n., d. n.

${ }^{29}$ MNL OL XIX-I-1-r. VKM KOLL 1950. április 6-i ülése.

${ }^{30}$ MNL OL XIX-I-1-r. VKM KOLL 1950. január 24-i ülése.

${ }^{31} 137 / 1951$. (VII. 7.) M. T. sz. rendelete az egyetemet, főiskolát vagy szakközépiskolát végzett hallgatók tervszerú munkába állításáról, valamint a tanulmányaikat folytató hallgatók alkalmazásának szabályozásáról. Közoktatásügyi Közlöny, 1. 1951. 4. sz. 85-86.; 35/1952. (V. 4.) M. T. sz. rendelet az egyetemi és főiskolai hallgatók munkaviszonyba lépésének szabályozásáról. Közoktatásügyi Közlöny, 2. 1952. 10. sz. 118.

${ }^{32}$ MNL OL M-KS 276-86/87. MDP Agitációs és Propaganda Bizottság 1951. november 26-i ülése.
} 
1950 decemberében például azt a feladatot kapták, hogy magyarázzák meg a hallgatóknak, hogy a vizsgákon ,a végzett munkáról kell beszámolniok, a munkáról való beszámoló pedig a szocialista társadalomban dicsőség" (a helyi DISZ ehhez azt a némiképp gyakorlatiasabb érvet is hozzátette, hogy a vizsgaeredményektől függnek az ösztöndíjak is). ${ }^{33}$ Faliújságok, röplapok, karikatúrák ${ }^{34}$ és vizsgahíradók buzdították a hallgatókat a konzultációkon való részvételre, a vizsgán való megjelenésre, ismertették a jó tanulók módszereit. A versenytáblák név szerint dicsérték a kiváló eredményeket elérőket, és csúfolták a lemaradókat: „Hatalmas sikere volt Benedek Pálnak az orosz vizsgán. (...) Erre való tekintettel a vizsgáztató óhajára meg kell ismételnie azt." - gúnyolódott a budapesti jogi kar vizsgahíradója 1952 januárjában. ${ }^{35}$ Azokat a hallgatókat, akiknél fennállt a veszélye, hogy nem jelennek meg a vizsgán, DISZ-brigádok vagy a tanulmányi osztály előadói keresték fel. Egy 1951. februári jelentés szerint a Múszaki Egyetemen az is többször előfordult, hogy a már zajló vizsgák közepette jelentek meg egy-egy olyan hallgatóval, aki eredetileg be sem akart jönni. ${ }^{36}$ Bár volt olyan DISZ-csoport, amelyik felismerte, hogy a vizsgára kényszerítés tulajdonképpen ugyanúgy bukáshoz és a csoportátlagok csökkenéséhez vezet, mint a távolmaradás, mindössze a korszakra oly jellemző következtetést vonták le: e jelenség ellen „harcolni kell”. 37

Az ötvenes évek eleji központi elképzelések szerint a tanulásnak egyetlen „igaz” útja létezett, mely azonban a korabeli jelentések szerint sem eredményezte a kívánt tanulmányi fegyelem kialakulását (sem a „fejekben”, sem a gyakorlatban ${ }^{38}$ ). A hit azonban, hogy az oklevél megszerzése pusztán az új és egyedül üdvözítőnek tekintett oktatás- és tanulásszervezés, valamint nevelés és meggyőzés kérdése, alapot adott a tanulmányi hanyagság és sikertelenség fegyelmi vétségként való kezeléséhez.

\section{A SZANKCIONÁLÁS ÉRVRENDSZEREI}

Ha egy felsőoktatási intézmény valamilyen tanulmányi vétség miatt fegyelmi eljárást indított, annak általában három - olykor egymással összefüggő, s

\footnotetext{
${ }^{33}$ MNL OL M-KS 276-89/332. Jelentés az Egri Pedagógiai Főiskola Pártszervezetének december havi munkájáról. Eger, 1950. december 30.

${ }^{34}$ Lásd például: Akinek nem inge, ne vegye magára. Körkép a munkafegyelemről. (1950. 03. 24.) Szabad Ifjúság, 4.

${ }^{35}$ Vizsgáznak a „vizsgahíradók”. (1952. 01. 31.) Szabad Ifjúság, 3. A vizsgaidőszakban zajló propagandatevékenységről lásd továbbá: MNL OL M-KS 276-89/312. A tanulás propagandájáról a harmincas évek szovjet egyetemein lásd: Konecny, 1999. 159-161. o.

${ }^{36}$ MNL OL M-KS 276-89/312. Az MDP XI. Kerületi Szervezete Múszaki Egyetem Üzemi Szervezetének jelentése az 50/51-es tanév I. félévének vizsgáiról. Budapest, 1951. február 2.

${ }^{37}$ MNL OL M-KS 276-89/332. Jelentés az egyetemi pártbizottságnak a PTE OK III. évfolyamának munkájáról. Pécs, 1951. április 15.

${ }^{38} \mathrm{Vö.} \mathrm{"A} \mathrm{munkafegyelem} \mathrm{inkább} \mathrm{külső.} \mathrm{A} \mathrm{folyamatos} \mathrm{tanulás} \mathrm{általában} \mathrm{csak} \mathrm{névleges,} \mathrm{vagy} \mathrm{még} \mathrm{az}$ sem." - jellemezte az ELTE magyarszakos hallgatóit Bárczi Géza 1952-ben. HUNG Eötvös Loránd Tudományegyetem Bölcsészettudományi Kara Tanácsának 1952. december 23-i ülése.
} 
együttesen jelentkező - oka lehetett: vagy maga akart megszabadulni egy-egy hallgatótól: az eljárással nyomást próbált gyakorolni egy hanyagnak vélt hallgatóra, hogy magatartását változtassa meg, vagy pedig példát kívánt statuálni.

Ha egy felsőoktatási intézmény úgy ítélte meg, hogy egy hallgató alkalmatlan felsőfokú tanulmányok folytatására, eltanácsolhatta. Ha egy hallgató tanulmányait abba kívánta hagyni, s emellett felhozott indokait az egyetem vagy a főiskola is nyomósnak találta, engedélyezhette távozását. Minden gyengének vélt hallgatót azonban nem bocsáthattak el, s a távozást sem engedélyezhették minden kérvényezőnek, ez ugyanis oly mértékú lemorzsolódást eredményezett volna, mely veszélyeztette az intézmény tervének teljesítését. Noha az eltanácsolás, a lemorzsolódás és a kizárás végső soron ugyanarra az eredményre vezetett, utóbbit viszont a pártszervek és a minisztérium nem problematikusnak, hanem a tanulmányi fegyelem megteremtéséért vívott „harc” érdekében egyenesen kívánatosnak tartották. ${ }^{39}$ Így a felsőoktatási intézményeknek nemcsak kötelessége, de érdeke is volt, hogy egy-egy hallgatót fegyelmivel távolítsanak el. Egyrészt, mert így eleget tehettek azoknak a felszólításoknak, hogy a tanulmányi fegyelmet nevelő célzatú kizárásokkal szilárdítsák meg, másrészt, mert a kizárás lehetőséget adott arra, hogy egy-egy gyengébb hallgatótól a központi bírálatok minimalizálásával szabaduljanak meg.

Abban ugyanis, hogy a mégoly indokolt tanulmányi nehézségeket vagy anyagi okokat sem fogadták el automatikusan a távozási szándék vagy a hanyagság indokaként, szerepet játszott, hogy olyan körülményekről volt szó, amelyeket az intézményeknek elvben tudniuk kellett kezelni, például konzultációval, tanulópár kijelölésével vagy az ösztöndíj megemelésével. Féléves, éves jelentéseikben a létszámcsökkenést és a romló átlagokat részletesen meg kellett magyarázniuk, kitérve arra, hogy mi mindent megtettek annak érdekében, hogy a távozókat maradásra bírják és a lemaradókat felzárkóztassák. ${ }^{40}$ A lemorzsolódók száma ugyanis a tanulmányi osztály „helytelen ösztöndíj-politikájára”, a tanárok nem megfelelő oktatási módszereire, politikai beállítottságára vagy egyáltalán arra utalhatott, hogy nem kísérik figyelemmel azokat a körülményeket, amelyek megnehezítik egy-egy hallgató számára az oklevél megszerzését. Mivel e kérdések fokozottan a tanszék vagy a tanulmányi osztály munkájára irányíthatták a figyelmet, nem meglepő, hogy a korabeli jelentések szerint a lemorzsolódni kívánó „munkás- és parasztszármazású", illetve szakérettségis hallgatókat a tanulmányi osztályok órákon át győzködték, szinte „körbeudvarolták”, hogy maradásra bírják őket, valamint az, hogy sok oktató nem vállalta a felelősséget megbuktatásukért, s inkább átengedték őket. ${ }^{41}$ A felelősség hárításának az

\footnotetext{
${ }^{39}$ MNL OL M-KS 276-86/87. MDP Agitációs és Propaganda Bizottság 1951. november 26-i ülése.

${ }^{40}$ Lásd például: MNL OL M-KS 276-89/332. MDP Szegedi Egyetemi és Főiskolai Pártbizottság információs jelentése. Szeged, 1950. december 30.

${ }^{41}$ Lásd például: MNL OL M-KS 276-89/312. Mûszaki felsőoktatási főosztály jelentése a félévi vizsgák kiértékeléséről. Budapest, 1951. február 24.; MNL OL M-KS 276-89/332. Jelentés a debreceni Tudományegyetem hallgatóinak I. félévi tanulmányok eredményéről [sic!]. Debrecen, 1951. február 3.
} 
Agitációs és Propaganda Bizottság szerint is szélsőséges példáját jelentette, hogy a miskolci egyetemen 1951-ben olyan nyilatkozatot írattak alá a lemorzsolódni kívánó hallgatókkal, melyben a tanulmányi osztály védelmében tulajdonképpen „ellenségnek" nyilvánították magukat: „Alulírott (...) gépészmérnök hallgató kijelentem, hogy önkényesen hagyom el az egyetemet, a tanulmányi osztályvezető és a tanulmányi osztálykáderes felvilágositó munkája ellenére. Tisztában vagyok azzal, hogy ezzel gátolom az ötéves terv és a szocializmus épitését, a tervszerü mérnökképzést." 42

A központi kritikákat hárítandó, az intézmények a fegyelmi eljárások során is hosszasan részletezték a segítségnyújtás különféle formáit, amellyel a lemorzsolódást vagy a kizárást megpróbálták megakadályozni. Ennek hangsúlyozását a Pécsi Pedagógiai Főiskola igazgatója 1952-ben még olyan hallgatók esetében is szükségesnek látta, akiknek jellemzése egyesek megdöbbentő alkalmatlanságáról tanúskodott, mások esetében pedig arról, hogy már hetek óta nem is látták őket: „Mind a föiskola Igazgatósága, mind pedig a Tanulmányi Osztály a most kizárásra javasolt hallgatók mindegyikével behatóan foglalkozott, amennyiben nehézségeik voltak[,] azokat minden rendelkezésre álló eszköz igénybevételével igyekeztünk megoldani, munkánk azonban eredménytelen maradt, s úgy látjuk, hogy a legnagyobb pedagógiai optimizmus sem ad reményt arra, hogy esetleg további nevelo" munkánk eredménnyel járna." 43

Az intézményi felelősség hárítását szolgálta az is, hogy ha egy hallgatót tanulmányi okokból zártak ki, ennek okát rendszerint hanyagsággal, lustasággal stb., tehát a hallgató valamilyen egyéni hibájával magyarázták. Rendkívül gyakori volt az az érvelés, amely a hallgatónak nyújtott segítség részletes felsorolásával egyszerre bizonyította az intézmény segítőkészségét és a hallgató elutasító magatartását: „E.-nak volt megjavulási ideje. Ez idő alatt tanulhatott volna, igénybe vehette volna mindazt a segítséget, amit az igazgatóság, a tanulmányi osztály és a tanszék biztosított számára. Neki azonban nem kellett a segítség. Tudatosan visszautasította". ${ }^{4}$ A fegyelmi bizottságok értelmezésében alig létezett olyan tanulmányi probléma, melyet ne lehetett volna kellő szorgalommal megoldani. Egy többszörösen bukott főiskolás hallgató például azzal indokolta lemaradását, hogy szülei megbetegedtek, s anyagilag támogatnia kellett őket, ráadásul ezzel egy időben zajlott válása is. Noha a Pécsi Pedagógiai Főiskola igazgatója elismerte problémái súlyosságát, mégis úgy vélte, hogy mivel „tanáraitól a legnagyobb támogatást megkapta”, ${ }^{5}$ tudnia kellett volna kezelni azokat: "[K]étségtelen az, hogy nagy nehézségekkel küzdött. (...) Ennek ellenére tanulmányi munkáját el tudta volna látni, ha kellö akarattal és szorgalommal rendelkezik. Az akarat hiánya azonban a

\footnotetext{
${ }^{42}$ MNL OL M-KS 276-54/175. Az MDP Titkárságának 1952. január 9-i ülése, 4/b. pont: Az egyetemi és főiskolai lemorzsolódás az 1950-1951-es tanévben.

${ }^{43}$ MNL OL XIX-I-5-a. 94. doboz, 8475-0126/1952. Vizsgával elmaradt hallgatók felülbírálása. Pécs, 1952. február 28.

${ }^{44}$ MNL OL XIX-I-5-a. 94. doboz, 8475-0613/1952. Jegyzőkönyv E. T. és társa fegyelmi tárgyalásáról. Pécs, 1952. június 2.

${ }^{45}$ MNL OL XIX-I-5-a. 213. doboz, 847/855-16/1953. Határozat Cs. J. fegyelmi ügyében. Pécs, 1952. november 28 .
} 
vizsgák letételében meggátolta" ${ }^{46}$

A felsőoktatási intézmények - főként a „munkás- és parasztszármazású” és a szakérettségis hallgatók esetében - általában ódzkodtak attól, hogy a tanulmányi sikertelenséget kizárólag tudásbeli hiányosságokra vezessék vissza. Egyrészt, mert ezeket elvben tanszéki segítséggel kellett kezelniük, másrészt, mert a teljesítmény értékelésében nemcsak szakmai, hanem politikai szempontokat is érvényesíteniük kellett. Szávai Nándor VKM-államtitkár már 1949-ben figyelmeztette a pedagógusokat, hogy fel kell hagyni a tanulmányi előmenetel "objektív" vizsgálatával, helyette "a szocializmus épitésének szubjektív akaratával” kell megítélni a tanulók teljesítményét. ${ }^{47}$ A MDP Központi Vezetőségének 1950. márciusi párthatározata pedig a szakmai szempontok kizárólagosságát egyenesen ellenséges cselekedetté nyilvánította, amikor a munkás- és parasztszármazású fiatalok lemorzsolódását igen nagy részben az ellenség „állitólagos "színvonal «-követelményeivel" és az ebből fakadó tömeges elbuktatásokkal magyarázta (Horváth, 1950. 458-459. o.; Tolnai, 1950. 723. o.). ${ }^{48}$ Ráadásul hiába viselt egy oktató minden korábbinál nagyobb felelősséget hallgatói előmeneteléért, a teljesítmény megítélésében a tanulmányi osztály, a minisztérium, a pártszervezet, de akár a DISZ is illetékesnek tekintette magát. A vizsgákat e szervek képviselői rendszeresen ellenőrizték, s az eredményekből az egész évi oktatómunkára, de a vizsgáztató politikai beállítottságára vonatkozó következtetéseket is levontak. ${ }^{49} \mathrm{Az}$ érdemjegyekről napi-heti rendszerességgel készültek a kimutatások, s minden esetben magyarázatra szorult, ha ezek a „munkás- és parasztszármazású” hallgatók lemaradását mutatták. Amikor 1950 júliusában a Múegyetem év végi vizsgáin azt tapasztalták, hogy a jelesek és kitûnők között átlag alatti a „munkás- és parasztszármazásúak” aránya, ellenben a jó, közepes és elégségesek között átlag feletti, a vizsgaellenőr a helyzetet csak politikai dimenziókban látta megmagyarázhatónak: „[A]z a feltevésem, hogy a munkáshallgatók eredményei egyrészt reálisabbak az átlagnál, másrészt viszont amikor a professzorok jelentékeny részben könnyebben adják az elmúlt időkhöz viszonyítva a kitünő és jeles minősitéseket, és erre a vizsgák során rá is jöttek, éppen itt akartak kompenzálni. (...) [E]z még mindég bizonyos elfogultságra mutat a munkáshallgatókkal szemben. (...) [Az előző félévben] a vizsgáztatók egy része opportunizmusból a munkáshallgatóknak a megérdemeltnél jobb jegyet adott. Most úgy látszik, hogy átestek a ló másik oldalára. Amennyiben azonban a félévi eredmények voltak reálisak, akkor a mostani eredményeket úgy kell értékelnünk, hogy a vizsgáztatók a munkáshallgatók terhére kedveztek a többieknek." ${ }^{50}$ E hozzáállásból fakadóan - mutat rá Lukács

\footnotetext{
${ }^{46}$ MNL OL XIX-I-5-a. 213. doboz, 847/855-16/1953. Cs. J. kizárása. Pécs, 1953. január 10.

${ }^{47}$ Szávai Nándor: Pedagógusaink és az új tanév. (1949. 09. 15.) Köznevelés, 490.

${ }^{48}$ A Magyar Dolgozók Pártja Központi Vezetőségének határozata a Vallás- és Közoktatásügyi Minisztérium munkájával kapcsolatos kérdésekről, 1950. március 29. In: Kardos József - Kornidesz Mihály (1990, összeáll.): Dokumentumok a magyar oktatáspolitika történetéböl. I. köt. 1945-1953. Tankönyvkiadó, Budapest, 377-380.

${ }^{49}$ MNL OL M-KS 276-89/328. Főbb szempontok a vizsgák ellenőrzéséhez. H. n., d. n.

${ }^{50}$ Lásd például: MNL OL M-KS 276-89/312. Feljegyzés. Budapest, 1950. július 4.
} 
Péter - a tanulók tudásának színvonala mint fogalom az ötvenes évek elején az iskolai teljesítmények értékelésében érvényesített osztályszempontok miatt értelmezhetetlenné vált, mivel az egyes tanulók esetében ahhoz másként kellett viszonyulni (Lukács, 1991. 15-30., 64. o.).

Noha az egyes jellemzések a hallgatók olykor megdöbbentő alkalmatlanságáról számoltak be, az egyéni felelősséget hangsúlyozó érvrendszer alkalmas volt arra, hogy az intézmény hivatalosan ne a tudásbeli hiányosságokat, hanem a helytelen tanulási módszereket szankcionálja, s ily módon zárójelbe tegye a problémák kialakulásáért felelős társadalompolitikára vagy oktatásszervezési gyakorlatra vonatkozó kérdéseket. Ahogy a párt az üzemekben a tervtől való elmaradást, valamint a tervgazdaság „üzemzavarai” nyomán kiéleződo társadalmi konfliktusokra adott válaszokat - mint a selejttermelést, az önkényes kilépéseket vagy igazolatlan hiányzásokat - elsősorban a munkafegyelem lazulásával magyarázta (Gyekiczky, 1989. 27-35. o.), a tanulmányi vétségek hátterében húzódó okok megállapítása is a hallgató jelleméből kiinduló egyéni, magatartásbeli magyarázatokra szorítkozott.

Ezen értelmezési keretben a tanulmányi elégtelenség nem a beiskolázási és a felvételi rendszer kontraproduktív jellegére, a mechanikus átirányításokból fakadó motivációhiányra, vagy épp a felsőfokú tanulmányokra alkalmatlanok nagyobb mértékú felvételére, tehát nem rendszerszintú problémákra (lásd Ladányi, 1986. 18-85. o., 1995. 489-491. o., 1999. 78-87. o.; Knausz, 1988/1998; Lukács, 1989; Sáska, 2006; Polyák, 2016) mutatott rá, sokkal inkább egy-egy hallgató lustaságaként értelmeződött. A fegyelmi határozatok tulajdonképpen a felsőoktatás szocialista átalakítását kísérő problémák bizonyítékát adták, anélkül, hogy az egyénen túlmutató okokra utaltak volna, hiszen az érvelés alapja az volt, hogy a hallgatónak nem volt akarata a nehézségeken felülemelkedni. Igy például hiába dokumentálta egy eljárás az átirányított hallgató motivációhiányát, ti., hogy a mérnöknek készülő, de pedagógiai főiskolára felvett hallgatónak nincs kedve tanulni, mivel nem jelent meg a neki felajánlott konzultációkon, gyenge eredményét arra vezették vissza, hogy alapvetően rossz a munkához való viszonya: „Passzív magatartásának megváltoztatására kello" ido állt volna rendelkezésére s nem menti az, hogy föiskolánkat nem érezte otthonának, mert ha a támogatást és a segítséget elfogadja, úgy a többi hallgatóval jól haladhatott volna."51

Hasonlóképp: a korabeli jelentésekből és fegyelmi esetekből részletes képet kaphatunk arról, hogy a hallgatók milyen változatos eszközökhöz folyamodtak, hogy megélhetésüket biztosítani tudják. Ennek leggyakoribb módja a tanulmányok melletti munkavállalás volt. Bár a nem megfelelő anyagi feltételek, a romló tanulmányi eredmények és a lemorzsolódás összefüggései az oktatásirányítás és a felsőoktatási intézmények számára sem voltak ismeretlenek, a probléma létét eleinte csak részben ismerték el, mivel úgy vélték, hogy az újonnan kialakított

\footnotetext{
${ }^{51}$ MNL OL XIX-I-5-a. 94. doboz, 8475-0613/1952. Jegyzőkönyv Cs. J. és társa fegyelmi tárgyalásáról. Pécs, 1952. június 2.
} 
kollégiumi, menza- és ösztöndíjrendszer általában fedezi a hallgatók kiadásait. A megélhetési problémára panaszkodók jó része esetében pedig úgy vélték, hogy egyrészt nehézségeik abból adódnak, hogy szüleik nem hajlandók részt venni a továbbtanulás költségeinek biztosításában, másrészt, hogy nincs is szó reális megélhetési problémákról, a hallgatók egy része pusztán anyagi okok mögé bújtatja tanulási nehézségeit. ${ }^{52}$

Az ösztöndíj megemelése vagy a munkavállalás engedélyezése azonban olyan segítség volt, melyet a hallgatónak tanulmányi munkájával kellett kiérdemelnie: "Az egyetemen senki azért nem járt rongyosan, mert tanult. Aki rendesen, becsületesen dolgozik, az kap segítséget" - rótta meg a Miskolci Nehézipari Múszaki Egyetem fegyelmi bizottsága 1952-ben egy munkavállalása miatt sokat hiányzó hallgatóját. ${ }^{53}$ Azt azonban, hogy egyes hallgatók anyagi nehézségeit a felsőoktatási intézmények valóban érzékelték, jól mutatja, hogy az önkényes lemorzsolódás miatt kizártak egy része esetében éppen anyagi körülményeikre hivatkozással tekintettek el az ösztöndíj visszafizettetésétől. ${ }^{54}$

Egyes hallgatók érvelése arra is rámutat, hogy néhányuknak éppen az új tanulásszervezési módszerek okoztak nehézségeket. Nem volt ritka, hogy a hiányzások vagy az órai jegyzetelés elmaradásakor arra hivatkoztak, hogy másik órára vagy vizsgára készültek. ${ }^{55}$ Ez persze, adott esetben, megfelelő kifogásnak is tû́nhetett, hogy elhárítsák a lustaság vádját, ám az a panasz, hogy a különféle kötelező elfoglaltságok szétforgácsolják a hallgatók idejét, más forrásokban is gyakran felbukkant, melyekből úgy túnik, hogy e kritikák függetlenek voltak a politikai öntudattól. 1951-ben egy funkcionárius hallgató éppen ideológiai-politikai érvekkel próbált meg rávilágítani a tanulásszervezés okozta túlterhelésre: „Sokszor úgy érzem magam, mint aki bilincsbe van verve, és nem tud mozdulni. Ilyenkor irigylem a szovjet diákokat, akik délután a könyvtárakba mennek tanulni. Ilyen nálunk elképzelhetetlen. Már harmadévesek vagyunk és ehhez képest nem vagyunk elég önállóak, nincs áttekintésünk a tárgyakról. Ilyen időfelaprózás mellett hogyan olvassuk el az új tankönyveket, hogyan legyen az ember munkája alkotó jellegü. Még akiben vannak is ilyen hajlamok, azt is elfojtja a túlterhelés, az időtlenség. [sic!]"56 A hallgatók olykor a foglalkozások minőségét is kritizálták: egy 1952-ben kizárt budapesti bölcsészhallgató például úgy nyilatkozott, hogy azért nem járt be és jegyzetelt órákon, mert olvasással jobban ki tudta használni az idejét, s ebben nem látott kivetnivalót, mivel úgy vélte, hogy „vannak olyan órák, amelyek csak

\footnotetext{
${ }^{52}$ MNL OL XIX-I-5-d. A Közoktatásügyi Minisztérium Kollégiumának (a továbbiakban: KM KOLL) 1951. augusztus 9-i ülése; KM KOLL 1951. november 22-i ülése.

${ }^{53}$ MNL OL XIX-I-5-a. 93. d. 8474-1651/1952. Jegyzőkönyv M. E. fegyelmi ügyében. Miskolc, 1952. október 6.

${ }^{54}$ Lásd például: MNL OL XIX-I-5-a. 215. doboz, 847/855-P1/2/1953. P. Gy. fegyelmi ügye.

${ }^{55}$ Lásd például: MNL OL XIX-I-5-a. 94. doboz, 8475-1324/1952. Jegyzőkönyv D. E. és mások fegyelmi tárgyalásáról. Szeged, 1952. november 18.

${ }^{56}$ Idézi: MNL OL M-KS 276-89/312. A félévi vizsgák értékelése egyetemi pártszervezeteink jelentései alapján. H. n., [1951].
} 
idővesztést jelentenek." 57

A tanulmányi hanyagság szankcionálásának erkölcsi-ideológiai hátterét azok az érvek jelentették, melyek a felsőfokú tanulmányok folytatását a hallgatók társadalmi munkamegosztásban elfoglalt pozíciójából fakadó kötelezettségként értelmezték. A fegyelmi eljárásokban alkalmazott érvrendszer nagy hasonlóságot mutat a munkafegyelem megsértőivel szemben hozott korabeli büntetôbírósági ítéletek - Gyekiczky Tamás által leírt - ideológiai érveivel. Ezen eljárások során a munkahelyről való önkényes kilépés vagy igazolatlan hiányzás olyan magatartásként jelent meg, mellyel a dolgozó a szocializmus felépítése érdekében kialakított munkaszervezési formák ellen vét, vagyis egyéni érdekeit a felsőbbrendûnek tekintett, össztársadalmi(ként deklarált) érdekek elé helyezve veszélyezteti utóbbiak megvalósítását, ezáltal pedig önmagának, kollektívájának, de általában véve a társadalomnak is kárt okoz. Vagyis tette helytelen és erkölcsileg elítélendő, de veszélyes is, így a közösség érdekében szankcionálandó (Gyekiczky, 1985).

A tanulmányi hanyagság miatt indított eljárások során a fegyelmi bizottságok a büntetés indoklására ugyanezt az érvrendszert használták, azzal a kiegészítéssel, hogy a társadalommal szemben fennálló kötelezettséget az is alátámasztotta, hogy a felsőfokú tanulmányokat egyfajta kegyként értelmezték, melyet a társadalom (máshol az állam, a párt vagy a munkásosztály) anyagi áldozatvállalása biztosít. Ez az érvrendszer nagy hangsúlyt fektetett az állam (párt) jóindulatának - vagy, ahogy Gyekiczky fogalmaz: a paternalista állam ethoszának (Gyekiczky, 1988. 106. o.) - demonstrációjára, így a kötelezettségek elhanyagolása azt is kifejezte, hogy a hallgató visszaélt a belé helyezett bizalommal és a neki nyújtott segítséggel, vagyis hálátlan, s így egyszerre anyagi és erkölcsi kárt okoz. Ez az indoklás jelent meg a Múszaki Tanárképző Főiskola egy hallgatónőjének 1952-es tárgyalásán, aki férjének vidéki áthelyezése miatt kívánta abbahagyni tanulmányait: „Maga itt egy évet töltött el, ami komoly pénzébe került az államnak. Magáért áldozatot hoztak. Ez mind a munkásosztály pénzéből van. Maga ezt minden további nélkül félredobja és eltávozik. (...) Mivel egészen abbahagyta tanulmányait, ezzel a társadalomnak nagy kárt tett." 58 Ebben az esetben a bizottság a lemorzsolódási szándék és az üzemi munkafegyelmi vétségek között is világos párhuzamot vont: „Önkényesen itthagytad az iskolát. Ha ezt üzemben csinálod, akkor azt mondják, hogy önkényesen elhagytad a munkát." 59

Az ideológiai alapú érvelés kifejezetten hasznosnak bizonyult a „munkásés parasztszármazású", illetve a szakérettségis hallgatók kizárásakor, ekkor ugyanis az intézmények több esetben is rámutattak arra, hogy a hallgatótól

\footnotetext{
${ }^{57}$ MNL OL XIX-I-2-f. 125. doboz, 847/855-N5/1954. Jegyzőkönyv N. Gy. DISZ-fegyelmi tárgyalásáról. 1951. december 15.

${ }^{58}$ MNL OL XIX-I-5-a. 213. doboz, 847/854-T10/1953. Jegyzőkönyv T. K.-né fegyelmi tárgyalásáról. Budapest, 1952. december 17.

${ }^{59}$ MNL OL XIX-I-5-a. 213. doboz, 847/854-T10/1953. Jegyzőkönyv T. K.-né fegyelmi tárgyalásáról. Budapest, 1952. december 17.
} 
- osztályhelyzetéből vagy a neki juttatott kiemelt támogatásból fakadóan nagyobb politikai öntudatot lehetett volna várni: „Maga az egyetemen is kap 420 Ft ösztöndíjat. Magának a népi demokrácia fanatikus harcosává kellene válni." - oktatott ki egy anyagi helyzete miatt panaszkodó szegedi hallgatót a tanulmányi osztály vezetője. ${ }^{60}$ E szempontból a „munkásszármazás” tulajdonképpen súlyosbító tényezőként hatott.

A fegyelmi bizottságok gyakran érveltek a hanyagság közvetlen környezetre gyakorolt hatásával is. E kitételek rendszerint úgy jelentek meg, hogy a hallgató „destruált", „lazította”, ,rombolta”, ,züllesztette”, „,bomlasztotta” társai fegyelmét vagy az "évfolyam szellemét". ${ }^{61}$ E negatív befolyás mérlegelése vezetett 1952-ben egy pécsi joghallgató két félévre történő felfüggesztéséhez, mely egyértelmúen az évfolyam közegéből való kiemelését szolgálta. A határozat szerint ugyanis bebizonyosodott, hogy, bár képességei erre megfelelőek (vagyis jó tanuló), a hallgató „nem áll a szocializmus épitése által elöírt követelmény, a tanulmányi rend, a tanulmányi fegyelem, az egyetemi rend pozitív oldalán", s "ha nem is hangadó", de „egész személye, adott esetben kialakitott magatartása jelszó, zászló azoknak a részére, akik valamely feladathoz nem jól viszonyulnak, de magatartásukat saját eszük alapján [!] nem képesek élesen vagy jól megindokolni."62 A hallgatótársakra gyakorolt negatív hatás felemlítése azért is jó érvnek számíthatott, hiszen megelőlegezte, hogy az oktatásirányítás kívánalmainak megfelelően a fegyelmi büntetés a közösségre nézve kedvező nevelő hatással fog járni.

A határozatok indoklásában a hanyagság közösségre gyakorolt úgymond pozitív hatása is a szankcionálás jogosságát támaszthatta alá, így például különösen hatásos érvnek számított az, hogy a fegyelmezetlen hallgató eltávolítását tanulmányi csoportja „követelte”. E megállapítások rendszerint a gondosan megkoreografált társadalmi bíróságok határozataira utaltak. A tanulmányi csoport, az évfolyam vagy akár az egész felsőoktatási intézmény nyilvánossága előtt lefolytatott tárgyalások során gyakran előre felkészített hozzászólók bírálták az igazolatlanul hiányzó, bukott társaikat, azt sugallva, hogy a "fegyelmezett többség" szemben áll a fegyelemsértővel. A társadalmi bíróságok elsődlegesen propagandaeszközök voltak, melyek a hanyagokat, lustákat, "lógósokat” megbélyegzo „közhangulat” meglétét igyekeztek demonstrálni. De nemcsak a büntetés alátámasztásában játszottak szerepet, hanem preventív célzattal az eljárásban közvetlenül nem érintett jelenlévők számára is tudtára adták, hogy mi minősül normaszegésnek (Fleck, 2001. 192-196. o.; Polyák, 2017).

Minthogy a tanulmányi eredményt a politikai lojalitás jelzőjének is tekintették, a kizárások ideológiai-erkölcsi alátámasztása olykor rendkívül súlyos bizo-

\footnotetext{
${ }^{60}$ MNL OL XIX-I-5-a. 94. doboz, 8475-1975/1952. Jegyzőkönyv K. J. és mások fegyelmi ügyében. Szeged, 1952. október 20.

${ }^{61}$ Lásd például: MNL OL XIX-I-2-f. 93. doboz, 8474-0122/1952. Jegyzőkönyv a Múszaki Egyetem Gépészmérnök Kar Tanulmányi Osztályának fegyelmi üléséről. Budapest, 1952. március 14.

${ }^{62}$ MNL OL XIX-I-5-a. 215. doboz, F847/855-V38/1953. Határozat V. E. fegyelmi ügyében. Pécs, 1952. április 29.
} 
nyítványt állított ki egy-egy hallgatóról. A hiányzások és bukások a tervteljesítés akadályozójaként, „,szabotálóként”, „Truman szekértolójaként”, ,dezertőrként”, tehát szinte ellenségként is feltüntethették őket, hivatalos papírt adva arról, hogy kárt okoztak az államnak, és munkájukkal nem hajlandók a szocializmus felépítésében közremúködni (vö. Kotkin, 1995. 207. o.; Szabó, 2007. 160-162. o.). A Pécsi Pedagógiai Főiskola egy önkényes távozása és költekező életmódja miatt kizárt hallgatójának ügyében született határozat efelől nem is hagyott kétséget: „Egész magatartása s az a tény, hogy 443.- Ft-os ösztöndiját nagyrészt szükségtelen dolgokra költötte el bizonyos mértékig ellenségesnek tekinthető [sic!]". ${ }^{63}$

A fegyelmi bizottságok a tanulmányi vétségeket egyes esetekben egyértelmúen politikai véleménynyilvánításként értelmezték, mely leggyakrabban az orosz nyelv oktatásával, illetve a katonai és a marxizmus-leninizmus órákkal kapcsolatos hanyagság esetében jelentkezett. Amikor egy átirányított hallgatónő 1952-ben önkényesen távozott a Budapesti Pedagógiai Főiskoláról, mondván nem akart és nincs is kedve oroszt tanulni, a fegyelmi bizottság a hozzáállását egyértelmúen politikai okokra vezette vissza: „az orosz nyelv és Főiskolánk lebecsülésével egyúttal a politikai hovatartozandóságáról is nyilatkozott, az orosz nyelv lebecsülése a Szovjetunióhoz való viszonyát tükrözi. [sic!]”64 Egy-egy hiányzásnak kiemelt jelentőséget tulajdoníthatott, ha kritikus időszakban történt, például egyházi ünnepek környékén. Egy szegedi vegyészhallgatóval például 1952-es fegyelmi tárgyalásán egyértelmúen közölték, hogy megkapta volna az engedélyt a hazautazásra, ha nem ragaszkodik november elsejéhez: „De november 1-ére senkinek sem adtunk hazautazási engedélyt, mert akkor mindenki hazautazott volna."65

Az ideológiai-politikai érvek felhasználása a hallgatóktól sem állt távol. Fellebbezéseikben többen hivatkoztak tervgazdasági szempontokra, annak az állandó propagandaelemnek az átvételével, miszerint az ötéves terv megvalósításához nélkülözhetetlen az „új értelmiség”: "Ötéves tervünkben nagy szükség lesz a tanult emberre, én is ki akarom venni részemet a szocializmus épitésében" érvelt egy szegedi hallgató 1952-ben, a tervgazdaság szükségletei mellett saját jó szándékáról is tanúságot téve. ${ }^{66}$

Noha több esetben előfordult, hogy a kérvényezők egyéni szempontokra, például elhivatottságukra hivatkoztak, többségük mégis igyekezett továbbtanulását az uralkodó politikai diskurzusnak megfelelően társadalmi érdekként feltüntetni. Változatos megfogalmazásokban, de a fellebbezések többsége rendszerint azzal zárult, miszerint a hallgató kész közremúködni az össztársadalminak deklarált célok megvalósításában. Egy pécsi joghallgató 1953-as fellebbezéséből például

\footnotetext{
${ }^{63}$ MNL OL XIX-I-5-a. 213. doboz, 8475/855-23/1952. Határozat J. J. fegyelmi ügyében. Pécs, 1952. november 28.

${ }^{64}$ MNL OL XIX-I-2-f. 126. doboz, 547/8551-5/1954. Fegyelmi jegyzőkönyv T. M. ügyében. Budapest, 1952. október 16.

${ }^{65}$ MNL OL XIX-I-5-a. 94. doboz, 8475-1324/1952. Jegyzókönyv a T.T.K. Hallgatói Fegyelmi Bizottság üléséről. Szeged, 1952. november 18.

${ }^{66}$ MNL OL XIX-I-5-a. 213. doboz, 8475-03131/1952. B. L. fellebbezése. Békéscsaba, 1952. november 11.
} 
alig vehető ki, személy szerint neki miért is fontosak tanulmányai, azokat ügyének pozitív elbírálása reményében - pusztán a tanulás szocialista értelmezési kereteinek megfelelően jelenítette meg: "Most is az az elgondolásom, hogy nem csupán a szellemiek, hanem emellett még a demokrácia épitését szolgáló téren is kivegyem részemet a munkából, amellyel szeretett Hazánk újjáépitésében gyakorlatilag is részt kívánnék venni, így szolgálva a szocializmust, a népet és így közelebb kerülni az élethez. (...) Kérem, tegye lehetövé (...), hogy (...) munkámmal ügyünket magam is elöre vigyem." 67

Ezekben az esetekben az a helyzet állt elő, hogy a kizárás mellett és ellene érvelők, tehát a fegyelmi bizottság és az érintett hallgató azonos vagy legalábbis nagyon hasonló ideológiai vagy propagandisztikus paneleket használtak fel ellentétes álláspontjaik alátámasztására. Míg a bizottságok arra mutattak rá, hogy a hallgató magatartása akadályozza a felsőoktatási terv teljesítését, vagy éppen, hogy semmi esély arra, hogy valaha is mérnököt, orvost, pedagógust stb. képezzenek belőle, a fellebbezők szintén a tervgazdasági érdekek sérelmeként jelenítették meg eltávolításukat, mely hátráltatja a szocializmus mielőbbi felépítését.

A felsőoktatásban az ötéves terv célkitûzéseinek megvalósítása során eleve abból kellett kiindulni, hogy az intézményi kapacitásokat a lehető leghatékonyabb módon kell kihasználni. A tanítás és tanulás voluntarista módon, pontosan tervezhetőnek és irányíthatónak vélt folyamatába pedig nem fért bele, hogy az oklevél megszerzése pusztán egyéni ambíció kérdése legyen.

A meggyőződés, hogy a tervcélok pusztán propagandával és új tanulási módszerekkel elérhetôk, a fegyelmet a végzettség megszerzésének legfontosabb előfeltételévé, olykor a felsőfokú tanulmányokra való alkalmatlanságot is pótló értékké emelte. A szocialista tanulásszervezés egyedül üdvözítő jellegébe vetett hitet jól mutatja, hogy önmagában a jó jegy megszerzése sem minősült érdemnek, ha az nem kijelölt időben történt: sikert csak egyetlen, központilag előírt módon lehetett elérni.

Mindebből fakadóan az egyes hallgatók tanulmányi nehézségekre adott reakcióit pusztán fegyelemlazulásként értelmezték. Mivel a felsőoktatási intézmények a korábbiakban nem tapasztalt mértékú felelősséget viseltek hallgatóik előmeneteléért, a tanulmányi nehézségek alátámasztására felvetett indokokat kételkedve fogadták, s saját oktatóik munkájának védelmében rákényszerültek, hogy maguk is tagadják ezen okok realitását, vagy a hallgatóra hárították annak ódiumát, hogy azokkal nem képes megbirkózni. A tanulmányi vétségek miatti fegyelmi eljárások megindítása számukra nemcsak központilag előírt és buzdított kötelezettség volt, hanem eszköz is arra, hogy egyes, felsőfokú tanulmányokra alkalmatlannak vagy érdemtelennek vélt hallgatótól úgy szabaduljanak meg, hogy azt egyenesen a lemorzsolódás elleni (!) harc követelményeként jelenítsék

\footnotetext{
${ }^{67}$ MNL OL XIX-I-5-a. 214. doboz, F847/855-C13/1953. Cs. Sz. M. fellebbezése. Dunaföldvár, 1953. március 28.
} 
meg. Ily módon a felsőoktatási intézmények - sokszor nem ideológiai-politikai, hanem szakmai és önvédelmi szempontjaikra tekintettel, de - hozzájárultak a kommunista hatalomgyakorlás e módjának igazolásához (vö. Apor, 2008. 38. o.).

Nyilvánvalóan hiba volna valamennyi késést, hiányzást vagy bukást „rendszerszintú" jelentőségúvé avatni. A fegyelmi eljárás alá vont hallgatók között minden bizonnyal voltak olyanok, akiknek hanyagsága valóban pusztán egyéni tényezőkre vezethető vissza. A korabeli fegyelmi gyakorlatra azonban jellemző, hogy azokat is fegyelemsértőként kezelték, akik valóban indokoltan hivatkoztak olyan problémákra, melyek a felsőoktatás ötvenes évek eleji múködési mechanizmusaival álltak összefüggésben.

Hiába dokumentálták az eljárások során született iratok maguk is e problémák létét, azokat elfedte a szankcionáláshoz kapcsolódó ideológiai-politikai érvelés, mely megfelelő politikai öntudattal az egyéni motiváció és az előképzettség hiányát, a munkáscsaládból érkezők iskolai szocializációs problémáit, vagy a továbbtanuláshoz elégtelen financiális hátteret, illetve ennek az egyre romló életszínvonalból fakadó beszúkülését is kompenzálhatónak vélte. Így a pusztán lusta és a valóban nehézségekkel küzdő hallgató egy fegyelmi kizárással ugyanazt a politikai bizonyítványt kapta, ti., hogy nem múködött közre a szocializmus felépítésében.

A tanulmányi sikertelenség fegyelmi vétségként való értelmezése 1953 után megváltozott. Bár ez elvi szinten szoros összefüggésben állt az addig kialakított felvételi és módszertani gyakorlatok kontraproduktivitásának elismerésével, gyakorlati lépésekre csak a Nagy Imre-féle új szakasz gazdaságpolitikai hangsúlyáthelyezése és a felsőoktatás finanszírozásának jelentős csökkentése után került sor. A mindenáron való oklevélszerzés erőltetése akkor enyhült, amikor a feszített beiskolázással felduzzasztott évfolyamok végzőseinek elhelyezése 1953-54-től a betölthető álláshelyek csökkenése miatt már meglehetős nehézséget okozott.

Ekkortól az oktatásirányításnak már nem volt érdeke, hogy valóban minden hallgató kezébe oklevelet adjon, így a felsőfokú tanulmányokra alkalmatlanok kimaradását maga is ösztönözte: 1953 decemberében az Oktatásügyi Minisztérium úgy rendelkezett, hogy az intézmények engedjék el az átirányításukkal elégedetlen hallgatókat, az alkalmatlanokat pedig a félév végén tanácsolják el (Ladányi, 1986. 103. o.). Bár az igazolatlan hiányzás, az engedély nélküli munkavállalás, a bukás és általában a hanyagság továbbra is fegyelmi vétség maradt, az eljárások intézményi funkciója megváltozott. Ekkortól elsősorban a továbbra is bent tartani kívánt hallgatók megrendszabályozására szolgáltak, kizárásra egyre ritkábban került sor. Ha ugyanis egy felsőoktatási intézmény tanulmányi okok miatt maga kívánt megszabadulni egy hallgatójától, ekkortól kevésbé volt szüksége a fegyelmi úton történő, önigazolást szolgáló kizárásra, könnyebben megtehette, hogy eltanácsolja a diákot. 


\section{LEVÉLTÁRI FORRÁSOK}

Magyar Nemzeti Levéltár Országos Levéltára (MNL OL)

$\begin{array}{ll}\text { M-KS 276-86. } & \begin{array}{l}\text { Magyar Dolgozók Pártja, Agitációs és Propaganda Bizottság } \\ \text { (Kollégium) iratai (1948-1953) }\end{array} \\ \text { M-KS 276-89. } & \begin{array}{l}\text { Magyar Dolgozók Pártja, Agitációs és } \\ \text { Propaganda Osztály iratai (1950-1956) } \\ \text { Vallás- és Közoktatásügyi Minisztérium, }\end{array} \\ \text { XIX-I-1-h. } & \begin{array}{l}\text { Felsőoktatási és Tudományos Főosztály iktatott iratai } \\ (1945-1951)\end{array} \\ \text { XIX-I-1-r. } & \begin{array}{l}\text { Vallás- és Közoktatásügyi Minisztérium, } \\ \text { Kollégiumi értekezletek (1949-1951) }\end{array} \\ \text { XIX-I-2-f. } & \begin{array}{l}\text { Oktatásügyi Minisztérium, Általános iratok (1954-1957) } \\ \text { XIX-I-5-a. }\end{array} \\ \text { Közoktatásügyi Minisztérium, Általános iratok (1952-1953) } \\ \text { XIX-I-5-d. } & \begin{array}{l}\text { Közoktatásügyi Minisztérium, } \\ \text { Kollégiumi értekezletek (1951-1953) }\end{array} \\ \text { HUNG } & \text { Hungaricana Közgyújteményi Portál, Egyetemi jegyzőkönyvek }\end{array}$

\section{IRODALOM}

Apor Péter (2008): A mindennapi élet öröme. In: Horváth Sándor (szerk.): Mindennapok Rákosi és Kádár korában. Új utak a szocialista korszak kutatásában. Nyitott Könyvmúhely, Budapest. 13-49.

Ágoston György (1952a): A tanulmányi csoportokkal való foglalkozás a szegedi Pedagógiai Főiskolán. Felsőoktatási Szemle, 1. 3. sz. 128-132.

Ágoston György (1952b): A fegyelemre nevelés néhány kérdése. Felsőoktatási Szemle, 1. 12. sz. 456-460.

Ágoston György (1962): A kommunista erkölcs tartalma és az erkölcsi nevelés feladatai. Tankönyvkiadó, Budapest.

Borbély András és Durkó Mátyás (1957): Jutalmazás és büntetés a szocialista fegyelem megteremtésében. Tankönyvkiadó, Budapest.

Borsodi Csaba (2003): Az egyetem a XX. század második felében 1945-2002. In: Szögi László (szerk.): Az Eötvös Loránd Tudományegyetem története, 1635-2002. Budapest. 305-382.

Csatár György (1951): A szocialista munkafegyelemről. Társadalmi Szemle, 6. 9. sz. 694-706.

Darvas József (1952): Hazafias nevelés iskoláinkban. Társadalmi Szemle, 7. 6-7. sz. 543-560.

Falusné Szikra Katalin (1955): A szellemi és a fizikai munka viszonyáról hazánkban. Közgazdasági Szemle, 2. 3-4. sz. 345-365. 
Fitzpatrick, Sheila (1993/2000): Ascribing class: the construction of social identity in Soviet Russia. In: Fitzpatrick, Sheila (ed.): Stalinism. New directions. Routledge, London-New York, 2000. 20-46.

Fleck Zoltán (2001): Jogszolgáltató mechanizmusok az államszocializmusban. Totalitarizmus-elméletek és a magyarországi szocializmus. Napvilág Kiadó, Budapest.

Foucault, Michel (1990): Felügyelet és büntetés. A börtön története. Gondolat Kiadó, Budapest.

Fukász György (1961): Oktatási rendszerünk továbbfejlesztésének néhány filozófiai problémája. Magyar Filozófiai Szemle, 5. 1. sz. 13-31.

Fukász György (1962): A szellemi és a fizikai munka közötti ellentmondás megoldása feltételeinek kialakulása a Magyar Népköztársaságban. Magyar Filozófiai Szemle, 6. 6. sz. 881-897.

Garai Imre (2015): Tudománypolitika és felsőoktatás Magyarországon, 19481951. In: Németh András, Bíró Zsuzsanna Hanna és Garai Imre (szerk.): Neveléstudomány és tudományos elit a 20. század második felében. Gondolat Kiadó, Budapest, 2015. 165-175.

Garai Imre (2016): A magyar felsőoktatás strukturális átalakítási kísérletei az 1949-1953 közötti időszakban. In: Németh András, Garai Imre és Szabó Zoltán András (szerk.): Neveléstudomány és pedagógiai kommunikáció a szocializmus időszakában. Gondolat Kiadó, Budapest. 119-160.

Golnhofer Erzsébet (2004): Hazai pedagógiai nézetek. Iskolakultúra, Pécs.

Gyekiczky Tamás (1985): Ideológiai érvek a munkafegyelem megsértőivel szemben az 1952-ben hozott büntetőbírósági ítéletekben. A budapesti Eötvös Loránd Tudományegyetem Állam-és Jogtudományi Karának actái, 27. 200-210.

Gyekiczky Tamás (1988): „A szót leírják”. Empirikus adatok az ötvenes évek ideológiai szerkezetének elemzéséhez. Társadalomkutatás, 6. 1. sz. 101-109.

Gyekiczky Tamás (1989): A fegyelem csapdájában. Munkafegyelmi kampányok társadalmi hatásainak elemzése. MTA Szociológiai Intézete, Budapest.

Horváth Márton (1950): Közoktatásügyünk a Központi Vezetőség határozata után. Társadalmi Szemle, 5. 6. sz. 450-460.

Knausz Imre (1988/1998): Az MDP és a közoktatás kérdései az iskolák államosítása után. In: Knausz Imre: Történelem és oktatás. Fővárosi Pedagógiai Intézet, Budapest. 69-99.

Konecny, Peter (1999): Builders and Deserters: Students, State, and Community in Leningrad, 1917-1941. McGill-Queen's University Press, Montreal.

Kotkin, Stephen (1995): Magnetic Mountain. Stalinism as a Civilization. University of California Press, Berkeley.

Krémer Miklós (1950): A munkafegyelemről. Jogtudományi Közlöny, 5. 1-2. sz. 13-19.

Ladányi Andor (1986): Felsőoktatási politika, 1949-1958. Kossuth Kiadó, Budapest.

Ladányi Andor (1995): A felsőoktatási felvételi rendszer történeti alakulása. Educatio, 4. 3. sz. 485-499. 
Ladányi Andor (1999): A magyar felsőoktatás a 20. században. Akadémiai Kiadó, Budapest.

Lukács, Péter (1989): Changes in Selection Policy in Hungary: the case of the admission system in higher education. Comparative Education, 25. 2. sz. 219-228.

Lukács Péter (1991): Színvonal és szelekció. Educatio, Budapest.

Makarenko, A. Sz. (1949a): A fegyelem. In: Makarenko, A. Sz.: Válogatott pedagógiai tanulmányok. Új Magyar Könyvkiadó, Budapest. 271-280.

Makarenko, A. Sz. (1949b): Fegyelem és fegyelmezés, büntetés és ösztönzés. In: Makarenko, A. Sz.: Válogatott pedagógiai tanulmányok. Új Magyar Könyvkiadó, Budapest. 92-115.

Makarenko, A. Sz. (1949c): Az egyéni ráhatás pedagógiája. In: Makarenko, A. Sz.: Válogatott pedagógiai tanulmányok. Új Magyar Könyvkiadó, Budapest. 116-139.

Nagy Mária (2015): X-esek. In: SAÁD József (szerk.): Hortobágy örökségei: kényszermunkatáborok és lakóik nyomában. Budapest, 2015. http: / /www . tele pesek.hu/pdf/muhely_X-es.pdf [2019.07.01.]

Németh András (2014): Emberi idővilágok. Pedagógiai megközelitések. Gondolat Kiadó, Budapest.

Németh András és Biró Zsuzsanna Hanna (2016): A magyar neveléstudomány diszciplína jellemzőinek és kognitív tartalmainak változásai a 20. század második felében. In: Németh András, Garai Imre és Szabó Zoltán András: Neveléstudomány és pedagógiai kommunikáció a szocializmus időszakában. Gondolat Kiadó, Budapest. 7-118.

Polyák Petra (2016): „A hallgatóknak meg kell lenni”. A felsőoktatási beiskolázás és felvételi rendszere az elsö ötéves terv idején. PTE, Pécs.

Polyák Petra (2017): Társadalmi bíróságok a felsőoktatásban az ötvenes évek elején. In: Kovács Janka, Kökényessy Zsófia és Lászlófi Viola (szerk.): A normán innen és túl. Történeti Kollégium, Budapest, 79-94.

Sarija, P. A. (1951): A kommunista erkölcs néhány kérdése. Szikra Könyvkiadó, Budapest.

Sáska Géza (2006): A társadalmi egyenlőség megteremtésének kísérlete az ötvenes évek felsőoktatásában. Educatio, 15. 3. sz. 593-608.

Siskin, A. (1955): A kommunista erkölcs alapjai. Szikra Könyvkiadó, Budapest.

Somogyvári Lajos (2016): Munkára nevelés a szocialista pedagógiában: az orosz-szovjet előtörténet (1917-1958). Iskolakultúra, 26. 1. sz. 82-82.

Szabó Márton (2007): A dolgozó mint állampolgár. Fogalomtörténeti tanulmány a magyar szocializmus három korszakaszáról. Korall, 8. 27. sz. 151-171.

Szita János (1951): A szakképzett munkaerő kérdése szocialista építésünkben. Társadalmi Szemle, 6. 5. sz. 379-394.

Takács Róbert (2008): A származási megkülönböztetés megszüntetése 1962-1963. Napvilág Kiadó, Budapest.

Timár János (1989): Hatalom és döntésképtelenség. Az oktatáspolitika és az oktatástervezés négy évtizede, 1948-1955. Közgazdasági és Jogi Könyvkiadó, Budapest. 
T. Kiss Tamás (1993): A magyarországi kulturális minisztériumokról (1867-1993). Konferencia Központ és Szabadegyetem Alapítvány, Budapest.

Tolnai Gábor (1950): Felsőoktatásunk a szocializmus építésében. Társadalmi Szemle, 5. 9. sz. 718-725.

Weltner Andor (1950): A szocialista munkafegyelem. Jogtudományi Közlöny, 5. 3-4. sz. 62-67. 